\title{
Potensi Pemanfaatan Atap Tribun Stadion Kapten I Wayan Dipta Gianyar sebagai PLTS Rooftop
}

\author{
Gallant Pradika ${ }^{1}$, Ida Ayu Dwi Giriantari ${ }^{2}$, I Nyoman Setiawan ${ }^{3}$ \\ [Submission: 09-11-2020, Accepted: 29-11-2020]
}

\begin{abstract}
Photovoltaic (PV) rooftop is an alternative option for clean and does not need to occupay special space just roof of the building to fulfill the energy needs. PV rooftop can be installed in a large area roof such as the roof of Stadium Kapten Dipta that is 1.259,76 meter square. PV power plant on Captain I Wayan Dipta Stadium rooftop is designed as an additional power supply to meet the stadium's electrical load needs. The rooftop power plant design uses 2 scenarios. Scenario 1 has a capacity of 83,300 Wp with 238 units of solar modules and 2 units of inverter producing 112,321 kWh/year of energy and will supply the day load of stadium transformers 2 and 3 with the total of 35,470 $\mathrm{kWh} /$ year. Scenario 2 has a capacity of $156,800 \mathrm{Wp}$ with 448 solar modules and 4 inverters producing $211.458 \mathrm{kWh} /$ year of energy and will supply whole stadium's transformer daylight load of $100,919 \mathrm{kWh} /$ year. The investment cost of scenario 1 is IDR 1,178,760,000 with total revenue until the 25th year of IDR $1,090,635,084$ while in scenario 2 the investment cost is IDR $2,237,860,000$ and the total revenue until the 25th year is IDR $3,126,761,273$. This paper uses the NPV, PI, and DPP methods as its economic feasibility analysis. Based on the analysis, only scenario 2 is feasible because in the 25th year the income is greater than the investment. On the other hand, the total revenue of scenario 1 will only be the same as the investment cost in its 29th year.
\end{abstract}

Keywords - Photovoltaic rooftop, Electric Energy, Economic Feasibility

Intisari- Pembangkit Listrik Tenaga Surya (PLTS) atap merupakan salah satu pilihan alternatif pembangkit listrik ramah lingkungan dengan memanfaatkan luas atap untuk memenuhi kebutuhan energi listrik yang tinggi. PLTS dapat dipasang pada wilayah yang luas seperti atap bangunan. Salah satu atap yang bisa dimanfaatkan adalah atap tribun stadion Kapten Dipta dengan luas atap dari tribun $1.259,76 \mathrm{~m}^{2}$.PLTS atap stadion Kapten I Wayan Dipta dirancang sebagai catu daya tambahan untuk memenuhi kebutuhan beban listrik stadion. Perancangan PLTS atap menggunakan 2 skenario. Skenario 1 memiliki kapasitas 83.300 Wp dengan modul surya sejumlah 238 unit dan inverter 2 unit menghasilkan energi $112.321 \mathrm{kWh} /$ tahun dan akan menyuplai beban siang trafo 2 dan 3 stadion sebesar $35.470 \mathrm{kWh} /$ tahun. Skenario 2 berkapasitas $156.800 \mathrm{Wp}$ dengan modul surya sejumlah 448 unit dan 4 inverter menghasilkan energi sebesar 211,458 $\mathrm{kWh} /$ tahun dan akan menyuplai beban siang trafo 1 stadion sebesar $100.919 \mathrm{kWh} /$ tahun. Biaya investasi

\footnotetext{
${ }^{1}$ Mahasiswa, Program Studi Teknik Elektro Fakultas Teknik Universitas Udayana, Jln. Kampus Bukit Jimbaran 80361 INDONESIA (telp: 0361-703315; e-mail: maestro.gp21@gmail.com)

${ }^{2,}{ }^{3}$ Dosen, Program Studi Teknik Elektro Fakultas Teknik Universitas Udayana, Jln. Kampus Bukit Jimbaran 80361 INDONESIA (telp: 0361-703315; fax: 0361-432103315; e-mail: dayu.giriantari@unud.ac.id,setiawan@unud.ac.id)
}

Gallant Pradika: Potensi Pemanfaatan Atap Tribun ... skenario 1 sebesar Rp.1.178.760.000 dengan total pendapatan sampai tahun ke-25 sebesar Rp.1.090.635.084 sedangkan pada skenario 2 biaya investasi sebesar Rp.2.237.860.000 dan pendapatan sampai tahun ke-25 sebesar Rp.3.126.761.273 Pada analisis kelayakan ekonomi menggunakan metode NPV, PI, dan DPP hanya skenario 2 yang dapat dikatakan layak karena pada tahun ke-25 pendapatan lebih besar dari investasi, sedangkan pada skenario 1 pendapatan akan bernilai sama dengan investasi saat tahun ke-29.

Kata Kunci- PLTS Atap, Energi Listrik, Kelayakan ekonomi

\section{PENDAHULUAN}

Kebutuhan masyarakat akan energi listrik di Indonesia setiap tahunnya semakin meningkat seiring pertumbuhan ekonomi dan teknologi yang sangat pesat. Statistik ketanagalistrikan menyebutkan tahun 2012 total penjualan tenaga listrik PLN sebesar 173,991 MWh rata-rata meningkat tiap tahunnya sebesar 4,97\% hingga tahun 2017 sebesar 221,575 MWh. [1] Sumber energi terbarukan salah satunya adalah energi matahari atau surya. Indonesia memiliki potensi energi matahari sebesar $4,8 \mathrm{kWh} / \mathrm{m} 2$ setara dengan 112.000 GWp, tetapi energi yang baru dimanfaatkan sekitar $10 \mathrm{MWp}$. [2] Provinsi Bali merupakan salah satu provinsi yang memiliki potensi energi surya yang cukup besar. Namun pada kenyataannya, pembangkit listrik yang berasal dari energi baru dan terbarukan hanya menyumbang $1 \%$ dari total pembangkit listrik yang ada di Provinsi Bali. [3]

Salah satu upaya pemerintah daerah provinsi Bali untuk meningkatkan penggunaan pembangkit listrik tenaga surya adalah dengan menerbitkan peraturan gubernur no 45 tahun 2019 tentang energi bersih Bali yang salah satu isinya mengatur desain atau tata letak bangunan yang memanfaatkan sinar matahari secara optimal. Dimana dalam peraturan tersebut menyebutkan bangunan yang memiliki luas lantai lebih dari $500 \mathrm{~m}^{2}$ harus menyediakan setidaknya $25 \%$ atap untuk solar panel. [4] Selain itu Bali juga memiliki potensi yang besar untuk memenuhi target PLTS Bali 108 MWh pada tahun 2025. [5].

Pembangunan pembangkit listrik tenaga surya pada umumnya memerlukan lahan yang cukup luas contohnya seperti PLTS Kayubihi yang memerlukan lahan seluas 1,5 hektar . namun pada beberapa kasus PLTS ini dapat dipasang di daerah pemukiman ataupun gedung-gedung perkantoran dengan memanfaatkan atap gedung tersebut. PLTS jenis ini biasa disebut rooftop solar panel. Beberapa gedung di Bali yang sudah memasang rooftop solar panel ini antara lain Gedung DH Program Studi Teknik Elektro Bukit Jimbaran [6], Gedung Kantor Gubernur Bali [7], atap gedung sekolah [8], atap gedung villa [9] dan gedung koperasi.. Selain untuk menyuplai beban listrik pada gedung, manfaat lain dari

p-ISSN:1693 - 2951; e-ISSN: 2503-2372 
pemasangan PLTS rooftop ini adalah kita dapat menjual kelebihan energi listrik kepada PLN yang ramah lingkungan.

Stadion Kapten I Wayan Dipta merupakan stadion pertandingan olahraga khususnya cabang sepak bola. Stadion Dipta yang bertempat di Desa Buruan, Kecamatan Blahbatuh, Gianyar ini merupakan stadion kebanggaan masyarakat Bali. Stadion ini berkapasitas 35.000 penonton dengan luas seluruh bangunan $\pm 30.000 \mathrm{~m}^{2}$. Stadion Kapten I Wayan Dipta Gianyar memiliki 3 buah trafo, dengan daya masing-masing trafo sebesar 197kVA, 82,5 kVA dan $66 \mathrm{kVA}$. Sehingga, total daya yang terpasang pada Stadion Kapten I Wayan Dipta adalah 345,5 kVA. Penggunaan energi listrik Stadion I Wayan Dipta setiap harinya tidak menentu tergantung ada tidaknya pertandingan di stadion tersebut. Untuk menyuplai kebutuhan beban stadion. Pengelola dapat memanfaatkan atap tribun stadion Kapten I Wayan Dipta sebagai PLTS Rooftop. Nantinya PLTS rooftop akan menghasilkan energi listrik dari cahaya matahari yang kemudian akan menyuplai beban pada saat stadion digunakan di siang hari.

Berdasarkan latar belakang diatas maka dalam usulan penelitian ini akan dilakukan penelitian tentang pemanfaatan atap tribun Stadion Kapten I Wayan Dipta sebagai PLTS Rooftop.

\section{KAJIAN PUSTAKA.}

\section{A. Pembangkit Listrik Tenaga Surya}

Pembangkit Listrik Tenaga Surya (PLTS) merupakan pembangkit listrik yang menfaatkan energi baru dan terbarukan berupa sumber energi matahari dalam bentuk energi cahaya. Pada saat cahaya matahari dalam bentuk foton melewati sel surya (fotovoltaik) maka cahaya tersebut akan dikonversikan menjadi energi listrik dalam bentuk arus searah yang nantinya akan diubah menjadi arus bolak-balik apabila diperlukan.[10]

Berdasarkan aplikasi dan konfigurasinya, PLTS dapat diklarifikasikan menjadi 2 yaitu [11] :

1. Off-Grid

Sistem PLTS yang tidak terhubung dengan jaringan PLN atau yang sering disebut PLTS berdiri sendiri (stand-alone) merupakan pembangkit listrik alternatif untuk menyuplai listrik di daerah-daerah terpencil yang tidak terjangkau oleh jaringan PLN. PLTS sistem Off-grid diantaranya PLTS terpusat, tersebar, dan hybrid.

2. On-Grid

merupakan sistem PLTS yang terhubung langsung dengan jaringan PLN, dengan mengoptimalkan pemanfaatan energi matahari oleh panel surya untuk menghasilkan energi listrik semaksimal mungkin. PLTS On-Grid diantaranya PLTS Rooftop dan PLTS skala utilitas.

Pembangkit Listrik Tenaga Surya secara umum terdiri dari beberapa komponen, antara lain :

1. Modul Surya.

Modul surya merupakan komponen utama dalam sistem PLTS yang berfungsi mengubah sinar matahari menjadi energi listrik. [12]

2. Inverter

Inverter memiliki fungsi mengubah listrik yang dihasilkan modul dan baterai yang berupa DC menjadi AC.

B. Sudut Kemiringan Modul Surya
Sudut kemiringan $(\beta)$ merupakan sudut diantara bidang solar modul dan horizontal. Ketika $(\beta)$ positif, maka permukaan modul mengahadap arah khatulistiwa dan ketika $(\beta)$ negatif, maka modul menghadap arah kutub. [13]

C. Aspek Ekonomi dan Analisis Ekonomis

Aspek Ekonomis meliputi biaya investasi dan biaya operasional. Biaya investasi merupakan biaya awal yang dibutuhkan untuk membangun sebuah PLTS, biaya ini meliputi biaya komponen, biaya pengadaan lahan, biaya instalasi dan biaya transportasi. Biaya investasi terdiri dari biaya langsung dan biaya tidak langsung. Biaya pemeliharaan dan operasional per tahun untuk PLTS umumnya sebesar 1\%$2 \%$ dari total biaya investasi, biaya pemeliharaan dan operasional PLTS meliputi pembersihan panel surya, biaya pemeliharaan serta pemeriksaan peralatan dan instalasi. [14]

Analisis kelayakan ekonomi dilakukan untuk mengevaluasi biaya investasi awal, analisis kelayakan ekonomi yang biasa digunakan adalah metode perhitungan Net Present Value (NPV), Profitability Index (PI) dan Discounted Payback Period (DPP)

1. Net Present Value (NPV)

Nilai Net Present Value dapat dihitung dengan total arus kas bersih dikalikan faktor diskonto tiap tahunnya dikurangi Initial Investment. Atau dapat dirumuskan sebagai berikut. [15]

$$
\mathrm{NPV}=\sum_{t=1}^{n} \frac{N C F t}{(1+i)^{t}}-\text { Initial Investmen }
$$

Dimana:

$\mathrm{NCFt}=$ Net Cash Flow periode tahun ke-1 sampai tahun ke-n

II $\quad=$ Investasi awal (Initial Investment)

$\mathrm{i} \quad=$ Tingkat diskonto

$\mathrm{n} \quad=$ Periode dalam tahun (umur investasi)

\section{Profitability Index}

Profitability Index menunjukan keuntungan yang didapat dari sebuah proyek dalam kurung waktu umur proyek, investasi dapat dikatakan layak jika PI harus lebih besar dari $1(1<)$, karena 1 merupakan titik impas antara nilai investasi dengan keuntungan. Nilai Profitability Index dapat dihitung dengan rumus sebagai berikut [15]

$$
\mathrm{PI}=\sum_{t=1}^{n} \frac{N C F t(1+i)^{-t}}{\text { Initial Investment }}
$$

\section{Discount Payback Period}

Discount Payback Period merupakan periode waktu pengembalian uang investasi yang dihitungan menggunakan discount factor. DPP dapat dicari dengan menghitung berapa lama nilai arus kas bersih setara dengan investasi awal. [16]

D. PVsyst

PVsyst merupakan software untuk mensimulasikan dan analisis modul surya PLTS. Keunggulan PVsyst adalah penggunaannya yang cukup mudah dan cepat. Antara lain : 
1. Menentukan energi yang diinginkan atau area yang tersedia untuk PLTS

2. Memilih modul dari internal database

3. Memilih inverter dari internal database

PVsyst akan megajukan array atau konfigurasi sistem yang dapat digunakan sebagai simulasi awal. PVsyst akan memberikan peringatan atau pesan eror jika terjadi kesalahan, atau ketidakcocokan pada desain PLTS dan akan diberikan sebuah peringatan.

\section{METODE PENELITIAN}

Penelitian ini dilakukan pada atap tribun stadion Kapten I Wayan Dipta Gianyar. Langkah awal dengan melakukan studi literatur dan identifikasi lokasi penelitan dan letak geografisnya. Kemudian mengumpulkan data penunjang penelitian seperti data AMR trafo, sistem kelistrikan,data iradiasi matahari dan komponen PLTS. Lalu melakukan perancangan PLTS menjadi 2 skenario, menghitung daya, energi dan beban yang dapat disuplai PLTS, langkah akhir melakukan perhitungan biaya energi dan kelayakan investasi PLTS. Setelah semua tahapan terpenuhi maka dapat ditarik kesimpulan. Alur penelitian dapat dilihat pada Gambar 1.

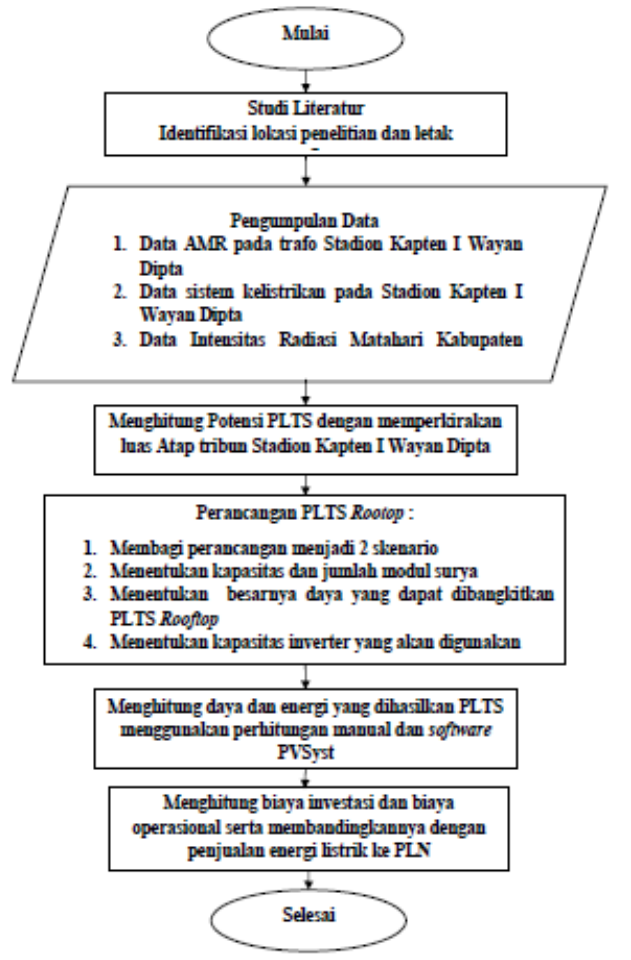

Gambar 1. Alur Penelitian

\section{EMBAHASAN}

IV.P

\section{A. Gambaran Umum Stadion}

Stadion Kapten I Wayan Dipta terletak di desa Buruan, Kecamatan Blahabtuh, Gianyar, Bali. Stadion ini merupakan stadion multifungsi yang utamanya digunakan untuk pertandingan sepak bola. Stadion Kapten I Wayan Dipta Gallant Pradika: Potensi Pemanfaatan Atap Tribun ... merupakan stadion tempat bermarkasnya klub sepak bola Bali United yang menjadi kebanggaan masyarakat Bali. Luas seluruh stadion adalah $\pm 30.000 \mathrm{~m}^{2}$ yang terdiri dari areal lapangan, tribun, café Bali United, Bali United Store, Game Centre, kantor DamKar, dan beberapa kantor olahraga kabupaten Gianyar.

Sumber daya listrik pada stadion Kapten I Wayan Dipta dibagi menjadi 2 yaitu dari trafo PLN dan generator set yang terdapat pada stadion. Daya listrik yang terpasang pada stadion sebesar 345,5 kVA yang dibagi menjadi 3 trafo :

$\begin{array}{lll}\text { a. } & \text { Trafo 1 } & : 197 \mathrm{kVA} \\ \text { b. } & \text { Trafo 2 } & : 66 \mathrm{kVA} \\ \text { c. } & \text { Trafo 3 } & : 82,5 \mathrm{kVA}\end{array}$

Trafo 1 menyuplai beban pertandingan kecuali lampu sorot stadion dan lampu led berjalan. Trafo 1 juga menyuplai kelistrikan pada café Bali United. Trafo 2 menyuplai kantor olahraga kabupaten Gianyar, dan trafo 3 menyuplai Bali United Store dan game centre. Generator set yang terdapat pada stadion ada 3 buah, 2 buah generator set untuk menyuplai lampu sorot stadion, dan 1 generator set menyuplai lampu led berajalan pada saat pertandingan berlangsung.

\section{B. Total dan Pola Beban Trafo Stadion Kapten I Wayan Dipta}

Sistem yang digunakan dalam perancangan PLTS tidak menggunakan baterai sebagai komponen penyimpanan energi, maka dari itu beban yang nantinya di suplai oleh PLTS hanya beban siang hari yaitu pada pukul 08.00-17.00. Hasil pengukuran energi listrik stadion Kapten I Wayan Dipta berdasarkan Automatic Meter Reading (AMR) PT. PLN Distribusi Bali dalam kurun waktu selama satu tahun yaitu periode bulan Oktober 2019 hingga September 2020 ditujunkan pada Tabel I. [17]

\section{Gambar 2. Pola Beban Maximum}

TABEL I

Beban Siang Bulanan Stadion Kapten I Wayan Dipta

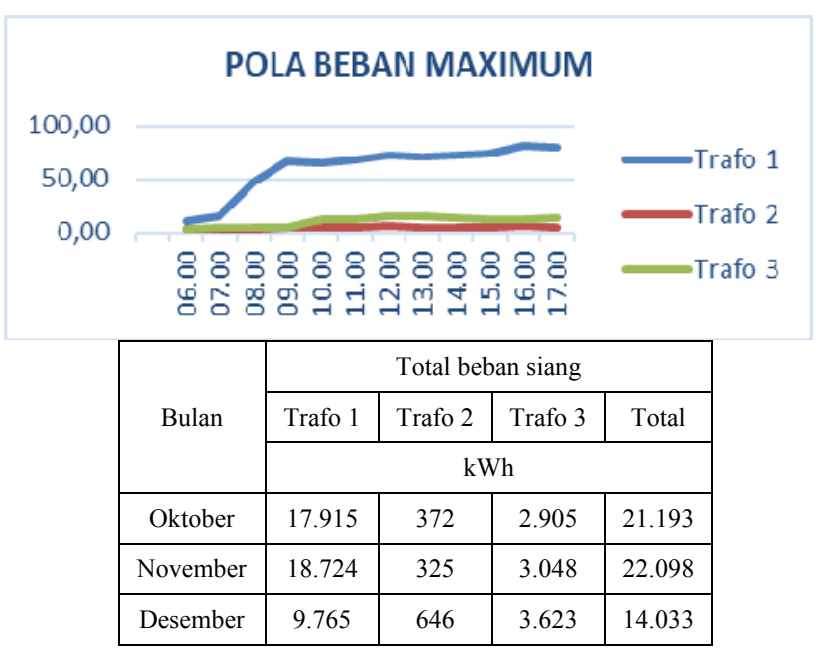

p-ISSN:1693 - 2951; e-ISSN: 2503-2372 


\begin{tabular}{|c|c|c|c|c|}
\hline Januari & 17.857 & 1.695 & 3.156 & 22.708 \\
\hline Februari & 7.799 & 50.837 & 3.860 & 62.496 \\
\hline Maret & 12.527 & 643 & 3.614 & 16.784 \\
\hline April & 12.160 & 257 & 3.407 & 15.824 \\
\hline Mei & 888 & 30 & 2.267 & 3.185 \\
\hline Juni & 633 & 0 & 1.609 & 2.242 \\
\hline Juli & 438 & 0 & 952 & 1.390 \\
\hline Agustus & 303 & 0 & 948 & 1.251 \\
\hline September & 1.909 & 2 & 1.612 & 3.523 \\
\hline
\end{tabular}

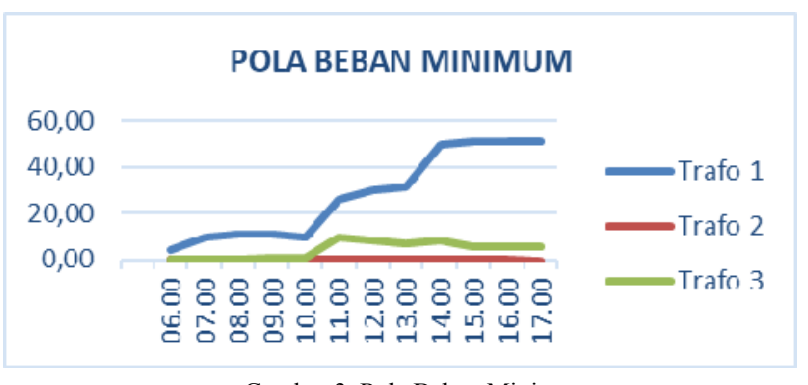

Gambar 3. Pola Beban Minimum

Pada Gambar 2 dan Gambar 3 menunjukan pola beban maximum dan minimum tiap trafo $(\mathrm{kW})$ pada siang hari mulai pukul 06.00 sampai 17.00. Pola beban ini dipengaruhi oleh penggunaan stadion yang berubah-ubah

\section{Menghitung Sudut Kemiringan Atap}

Jenis penyangga yang akan digunakan dalam instalasi PLTS adalah penyangga tipe tetap, maka harus ditentukan kemiringan atap untuk mendapatkan iradiasi yang optimal. Untuk menghitung sudut kemringan maksimum atap pertamatama mencari dahulu nilai ketinggian maksimum matahari dalam derajat $(\alpha)$ dengan menggunakan persamaan (3).

$$
\begin{aligned}
& \alpha=90^{0}+\text { lat }-\sigma \\
& \alpha=90^{0}+8,54^{0}-23,45^{0} \\
& \alpha=75,09^{0}
\end{aligned}
$$

Kemudian mencari sudut kemringan $(\beta)$ menggunakan persamaan (4)

$$
\begin{aligned}
& \beta=90^{\circ}-\alpha \\
& \beta=90^{\circ}-75,09^{0} \\
& \beta=14,91^{\circ}
\end{aligned}
$$

Jadi, sudut kemiringan optimal jika dipasang PV modul di atap stadion sebesar $14,91^{\circ}$. Namun, pada PV modul yang akan dipasang mengikuti sudut kemiringan atap tribun stadion sebesar $14,9^{0}$.

\section{Iradiasi Matahari}

Curah hujan menentukan besarnya iradiasi matahari, dimana iradiasi matahari merupakan faktor utama yang mempengaruhi keluaran energi dari PLTS. Pada perancangan PLTS stadion Kapten I Wayan Dipta digunakan iradiasi matahari pada wilayah Jimbaran tepatnya pada stasiun gedung Teknik Elektro Universitas udayana dengan menggunakan software HOBOware. Iradiasi ditunjukan pada Tabel II dengan asumsi nilai PSH konstan setiap harinya.
TABEL II

Rata-rata Iradiasi harian tahun 2018

\begin{tabular}{|c|c|}
\hline Bulan & $\begin{array}{c}\text { Iradiasi Harian } \\
\left(\mathrm{kWh} / \mathrm{m}^{2} / \text { hari }\right)\end{array}$ \\
\hline Januari & 4.11 \\
\hline Februari & 4.26 \\
\hline Maret & 4.98 \\
\hline April & 5.10 \\
\hline Mei & 4.87 \\
\hline Juni & 3.48 \\
\hline Juli & 4.53 \\
\hline Agustus & 4.82 \\
\hline September & 5.64 \\
\hline Oktober & 5.18 \\
\hline November & 4.07 \\
\hline Desember & 3.80 \\
\hline Rata-rata & 4.57 \\
\hline
\end{tabular}

\section{E. Perancangan PLTS Atap Tribun Stadion Kapten I Wayan} Dipta Gianyar

Langkah awal merancang PLTS yaitu dengan menentukan modul surya yang akan digunakan. Pemilihan jenis modul surya menjadi hal penting, mengingat luas wilayah pemasangan yang dibatasi oleh luas atap tribun stadion Kapten I Wayan Dipta sebesar 1.259,76 $\mathrm{m}^{2}$ Untuk mendapat daya output yang besar, maka pemilihan modul surya didasari oleh kapasitas yang tinggi, efisiensi yang tinggi dan keterjangkauan harga serta ketersediaan barang dipasar Indonesia. Berdasarkan hal tersebut dipilih modul surya CSUN, CSUN350-72M dengan spesifikasi 350 Wp ditunjukan pada Tabel III.

TABEL III

Spesifikasi Modul Surya CSUN, CSUN350-72M

\begin{tabular}{|l|l|}
\hline \multicolumn{2}{|c|}{ Module Type CSUN350-72M } \\
\hline Maximum Power - Pmpp & $350 \mathrm{~W}$ \\
\hline Open Circuit Voltage - Voc & $46,9 \mathrm{~V}$ \\
\hline Short Circuit Current - Isc & $9,49 \mathrm{~A}$ \\
\hline Max Power Voltage - Vmpp & $38,2 \mathrm{~V}$ \\
\hline Maximum Power Current - Impp & $9,17 \mathrm{~A}$ \\
\hline Module Efficiency & $18,07 \%$ \\
\hline \multicolumn{2}{|c|}{ Maximum Ratings } \\
\hline Maximum System Voltage (V) & 1000 \\
\hline Series Fuse Rating (A) & 20 \\
\hline \multicolumn{2}{|c|}{ Material Data } \\
\hline Dimensions & $1956 \times 990 \times 40$ \\
\hline Weight & $22,0 \mathrm{~kg}$ \\
\hline
\end{tabular}

Modul surya merek CSUN dapat menghasilkan power maximum sebesar $350 \mathrm{~W}$ dengan efisiensi modul sebesar $18.07 \%$. tipe modul surya ini menggunakan tipe monokristal. Output daya yang dihasilkan PLTS sangat dipengaruhi oleh rugi-rugi/losses komponen dan sistem. Jenis losses dapat dilihat pada Tabel IV [18], [19]. 
TABEL IV

Jenis Losses pada PLTS

\begin{tabular}{|l|c|}
\hline \multicolumn{1}{|c|}{ Jenis Losses } & Presentase \\
\hline Losses Manufacture $^{*}$ & $3 \%$ \\
\hline Losses Soiling (debu)** & $5,5 \%$ \\
\hline Losses Temperature modul* & $5,7 \%$ \\
\hline Losses pengkabelan & $5 \%$ \\
\hline Total & $19,2 \%$ \\
\hline
\end{tabular}

Daya output yang dihasilkan 1 modul surya CSUN, CSUN350-72M $350 \mathrm{Wp}$ dapat dihitung dengan persamaan sebagai berikut :

$$
\begin{aligned}
\text { Daya Output } & =\text { Pmax }-(\text { Pmax } \times \text { rugi-rugi }) \\
& =350 \mathrm{~W}-(350 \mathrm{~W} \times 19,2 \%) \\
& =350 \mathrm{~W}-67,2 \mathrm{~W} \\
& =282,8 \mathrm{~W}
\end{aligned}
$$

Pemilihan inverter dilakukan dengan mempertimbangkan kapasitas PLTS yang akan dipasang pada atap stadion. Inverter harus memiliki kapasitas yang kurang lebih sama dengan output modul surya. inverter yang dapat digunakan adalah inverter merek Huawei technologies type SUN2000 $42 \mathrm{KTL}$ dengan kapasitas inverter 42kW. Dengan spesifikasinya ditunjukkan pada Tabel V.

TABEL V

Spesifikasi Inverter Huawei technologies SUN2000 42KTL

\begin{tabular}{|l|l|}
\hline \multicolumn{2}{|c|}{ SUN2000-42KTL } \\
\hline Max. Efficiency & $98.8 \%$ \\
\hline European Efficiency & $98.4 \%$ \\
\hline Max. DC UsablePower & $47,900 \mathrm{~W}$ \\
\hline Max. Input Voltage & $1000 \mathrm{~V}$ \\
\hline Max. DC Current & $88 \mathrm{~A}$ \\
\hline $\begin{array}{l}\text { Min. Operating Voltage / Start } \\
\text { Input Voltage }\end{array}$ & $200 \mathrm{~V} / 250 \mathrm{~V}$ \\
\hline Full Power MPPT Voltage Range & $580 \mathrm{~V} \sim 850 \mathrm{~V}$ \\
\hline \multicolumn{2}{|c|}{ Output } \\
\hline Rated AC Active Power & $42,000 \mathrm{~W}$ \\
\hline Max.AC Apparent Power & $47,000 \mathrm{VA}$ \\
\hline Max. AC ActivePower (cos $\varphi=1)$ & Default 47,000W; \\
\multicolumn{2}{|c|}{ Material Data } \\
\hline Rated Output Voltage & $92,000 \mathrm{~W}$ optional in \\
\hline Rated AC Grid Frequency & $277 \mathrm{~V} / 480 \mathrm{~V}, 3 \mathrm{~W}+\mathrm{PE}$ \\
\hline Max.Output Current & $50 \mathrm{~Hz} / 60 \mathrm{~Hz}$ \\
\hline \multicolumn{2}{|c|}{$56.6 \mathrm{~A}$} \\
\hline Dimensions (W $\times \mathrm{H} \times \mathrm{D})$ &
\end{tabular}

Inverter Huawei Technologies SUN2000 42KTL. Memiliki kapasitas sebesar $42 \mathrm{~kW}$ dengan efisiensi yang tinggi sebesar 98,8\%. Dengan maksimal tegangan masuk sebesar $1000 \mathrm{~V}$ dan maksimal arus masuk sebesar 88A.

Konfigurasi seri parallel modul surya sangat penting dilakukan dalam perencanaan PLTS, hal ini bertujuan untuk mengetahui tegangan dan arus yang masuk dari panel surya ke inverter. Adapun perhitungannya adalah sebagai berikut Diketahui :

Open Circuit Voltage (Voc) $\quad: 46.9 \mathrm{~V}$

Max Power Point Voltage (Vmpp) : $38.2 \mathrm{~V}$

Max Power Point Current (Impp) : 9.17 A

Gallant Pradika: Potensi Pemanfaatan Atap Tribun ...
Max. input current Inverter (A)

Min. DC input voltage Inverter

Max. DC input voltage Inverter

$: 88 \mathrm{~A}$

$: 250 \mathrm{~V}$

: $1000 \mathrm{~V}$

Konfigurasi Seri-Paralel Panel Surya

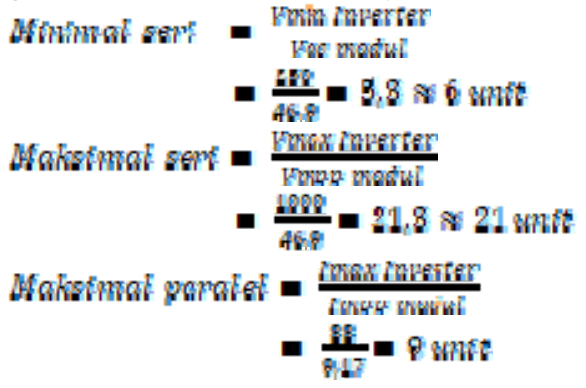

Berdasarkan hasil perhitungan dapat diketahui bahwa satu unit inverter dapat menampung modul surya yang dirangkai seri sebanyak 6-21 unit, sedangkan rangkaian paralel yang terhubung ke inverter maksimal berjumlah 9 rangkaian. Pada perancangan PLTS stadion Kapten I Wayan Dipta dimana perancangan dibatasi luas atap sebesar 1.259,76 $m^{2}$, maka konfigurasi seri paralel yang akan digunakan adalah 17 modul surya yang dirangkai seri dan 7 dirangkai paralel dengan menggunakan 2 inverter untuk skenario 1 . Desain skenario 1 ditunjukkan pada Gambar 4.

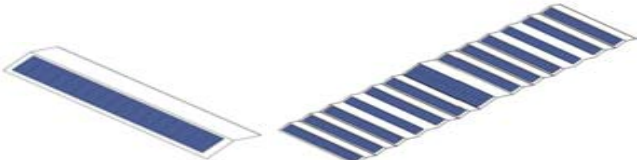

Gambar 4. Pemasangan modul surya pada atap bagian utara

Pada Gambar 4 dapat dilihat modul surya dipasang disatu sisi atap bagian utara sedangkan sisi atap bagian selatan dikosongkan.

Modul surya yang dapat dipasang berjumlah 238 unit. Besarnya daya yang bisa dibangkitkan PLTS sebesar 83.300 Wp. Dengan beban yang akan di suplai adalah trafo 2 dan 3 Dengan konfigurasi 7 string menyuplai trafo 2 dan 7 string menyuplai trafo 3 . Nantinya string tersebut akan digabungkan dengan combine box menjadi satu output yang akan dihubungkan ke inverter.

Pada Skenario 1 total modul yang akan dipasang berjumlah 238 unit. Jadi, total output daya yang dihasilkan adalah sebagai berikut.

$$
\begin{aligned}
\text { Total Daya Output }(\mathrm{Pi}) & =\text { Daya Output } \times \text { jumlah modul } \\
& =282,8 \mathrm{~W} \times 238 \\
& =67.306,4 \mathrm{~W} \sim 67,3 \mathrm{~kW}
\end{aligned}
$$

Untuk menghitung energi yang dihasilkan rata-rata pertahun, maka data iradiasi yang digunakan adalah iradiasi rata-rata, atau disebut Peak Sun Hour (PSH) yang besarnya menggunakan data iradiasi matahari pada Tabel II. Pada penilitian diasumsikan data iradiasi matahari yang digunakan data iradiasi matahari konstan tiap harinya. Pout dapat dihitung dengan persamaan sebagai berikut [20].

$$
\text { Pout }=\mathrm{Pi} \times \mathrm{PSH}
$$

p-ISSN:1693 - 2951; e-ISSN: 2503-2372 
Dimana:

Pout = Total energi output $(\mathrm{kWh})$

$\mathrm{Pi} \quad=$ Total daya output $(\mathrm{kW})$

PSH = Peak Sun Hour $\left(\mathrm{kWh} / \mathrm{m}^{2} /\right.$ hari

Kemudian dihitung untuk seluruh bulan selama setahun dengan PSH konstan maka didapatkan hasil pada Tabel iv TABEL VI

Perhitungan Energi Output Skenario 1

\begin{tabular}{|c|c|c|c|c|}
\hline \multirow{2}{*}{ Bulan } & \multirow{2}{*}{$\frac{\text { Iradiasi }}{\left(\mathbf{k W h} / \mathbf{m}^{2} / \mathbf{h a r i}\right)}$} & \multirow{2}{*}{$\mathrm{Pi}(\mathrm{kW})$} & \multicolumn{2}{|c|}{ Pout (kWh) } \\
\hline & & & Perhari & perbulan \\
\hline Januari & 4,11 & \multirow{12}{*}{67,3} & 276,6 & $8.574,69$ \\
\hline Februari & 4,26 & & 286,7 & $8.027,54$ \\
\hline Maret & 4,98 & & 335,15 & $10.389,77$ \\
\hline April & 5,1 & & 343,23 & $10.296,9$ \\
\hline Mei & 4,87 & & 327,75 & $10.160,28$ \\
\hline Juni & 3,48 & & 234,2 & $7.026,12$ \\
\hline Juli & 4,53 & & 304,87 & $9.450,94$ \\
\hline Agustus & 4,82 & & 324,39 & $10.055,97$ \\
\hline September & 5,64 & & 379,57 & $11.387,16$ \\
\hline Oktober & 5,18 & & 348,61 & $10.807,03$ \\
\hline November & 4,07 & & 273,91 & $8.217,33$ \\
\hline Desember & 3,8 & & 255,74 & $7.927,94$ \\
\hline \multicolumn{4}{|c|}{ Total (Energi yield) } & $112.321,681$ \\
\hline
\end{tabular}

Pada skenario 1 total energi yang dapat dibangkitkan PLTS sebesar 112.321,681 kWh atau sebesar 112.32 MWh.

Perancangan PLTS atap Stadion Kapten I Wayan Dipta bertujuan untuk menyuplai beban pada saat beroperasinya stadion. erhitungan energi yang menyuplai beban stadion pada skenario 1 dapat dilihat pada Tabel VII.

TABEL VII

Perhitungan Energi yang Disuplai PLTS Skenario 1

\begin{tabular}{|c|c|c|c|c|c|}
\hline \multirow{2}{*}{ Bulan } & Energi PLTS & \multicolumn{3}{|c|}{ Total beban siang } & \multirow{2}{*}{ Sisa Energi } \\
\cline { 2 - 6 } & Skenario 1 & Trafo 2 & Trafo 3 & Total & \\
\cline { 2 - 6 } & \multicolumn{5}{|c|}{ kWh } \\
\hline Oktober & 10.807 & 372 & 2.905 & 3.277 & 7.530 \\
\hline November & 8.217 & 325 & 3.048 & 3.373 & 4.844 \\
\hline Desember & 7.928 & 646 & 3.623 & 4.268 & 3.659 \\
\hline Januari & 8.575 & 1.695 & 3.156 & 4.850 & 3.724 \\
\hline Februari & 8.028 & 500,5 & $3.860,1$ & 4.361 & 3.667 \\
\hline Maret & 10.390 & 643 & 3.614 & 4.258 & 6.132 \\
\hline April & 10.297 & 257 & 3.407 & 3.664 & 6.633 \\
\hline Mei & 10.160 & 30 & 2.267 & 2.297 & 7.863 \\
\hline Juni & 7.026 & 0 & 1.609 & 1.609 & 5.417 \\
\hline Juli & 9.451 & 0 & 952 & 952 & 8.499 \\
\hline Agustus & 10.056 & 0 & 948 & 948 & 9.108 \\
\hline September & 11.387 & 2 & 1.612 & 1.613 & 9.774 \\
\hline Jumlah & 112.322 & 4.470 & 31.000 & 35.470 & 76.852 \\
\hline
\end{tabular}

Pada Skenario 1, beban stadion yang dapat disuplai adalah beban pada trafo 2 dan 3. Dari jumlah energi PLTS pada skenario 1 sebesar 112.322 mampu menyuplai beban trafo 2 dan 3 sebanyak $35.470 \mathrm{kWh}$ dan sisa energi dapat dijual ke grid sebanyak $76.852 \mathrm{kWh}$

\section{Suplai Daya PLTS Skenario 1}

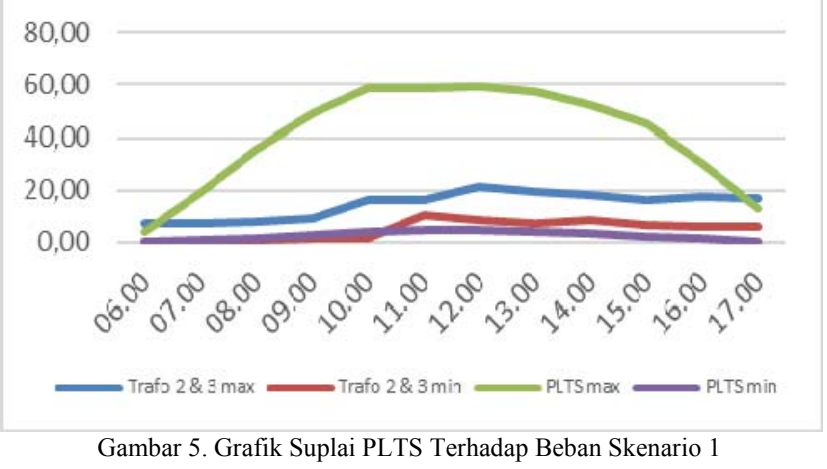

Pada Gambar 5 dapat dilihat pola pembangkitan daya PLTS menggunakan software PVSYST saat maximum dan minimum, pada saat PLTS beroperasi dalam keadaan maximum energi yang disuplai PLTS sanggup memenuhi kebutuhan beban trafo 2 dan 3, kemudian energi yang tersisa akan tersalurkan ke grid. Begitu pula sebaliknya saat PLTS tidak beroperasi secara maximum, kekurangan energi yang tidak dapat di suplai PLTS akan suplai oleh grid PLN. Hal ini dipengaruhi oleh cuaca pada saat PLTS beroperasi.

Pada skenario 2 konfigurasi nya adalah 16 dirangkai seri dan 7 dirangkai paralel dengan menggunakan 4 inverter.
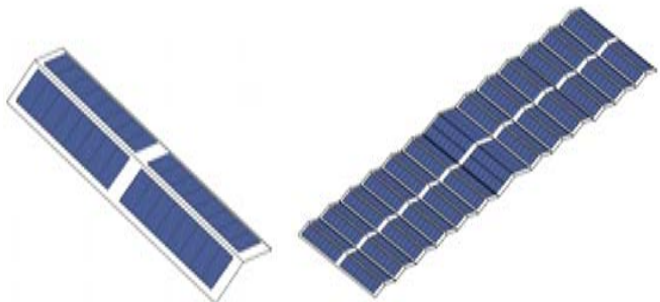

Gambar 6. Pemasangan modul surya pada kedua sisi atap

Pada Gambar 6 dapat dilihat modul surya dipasang pada kedua sisi atap dengan bagian tengah atap dikosongkan yang nantinya berguna untuk maintenance.

modul surya yang dapat dipasang berjumlah 448 buah. Besarnya daya yang bisa dibangkitkan PLTS sebesar 156.800 Wp. Pada Skenario 2 total modul yang akan dipasang berjumlah 448 unit. Jadi, total output daya yang dihasilkan dapat dihitung menggunakan persamaan (9.)

Total Daya Output $(\mathrm{Pi}) \quad=282,8 \mathrm{~W} \times 448$

$$
=126.694,4 \mathrm{~W} \sim 126,7 \mathrm{~kW}
$$

Total daya output modul surya yang didapat setelah dikurangi rugi-rugi besarnya $126,7 \mathrm{~kW}$. Dan Pout dapat dihitung menggunakan persamaan (10). Maka didapat hasil sebagai berikut. 
Perhitungan Energi Output Skenario 2

\begin{tabular}{|c|c|c|c|c|}
\hline \multirow{2}{*}{ Bulan } & \multirow{2}{*}{$\begin{array}{c}\text { Iradiasi } \\
\left(\mathbf{k W h} / \mathrm{m}^{2} / \mathrm{hari}\right)\end{array}$} & \multirow{2}{*}{$\mathrm{Pi}(\mathrm{kW})$} & \multicolumn{2}{|c|}{ Pout (kWh) } \\
\hline & & & Perhari & perbulan \\
\hline Januari & 4,11 & \multirow{12}{*}{126,7} & 520,74 & $16.142,85$ \\
\hline Februari & 4,26 & & 539,74 & $15.112,78$ \\
\hline Maret & 4,98 & & 630,97 & $19.559,95$ \\
\hline April & 5,1 & & 646,17 & $19.385,10$ \\
\hline Mei & 4,87 & & 617,03 & $19.127,90$ \\
\hline Juni & 3,48 & & 440,92 & $13.227,48$ \\
\hline Juli & 4,53 & & 573,95 & $17.792,48$ \\
\hline Agustus & 4,82 & & 610,69 & $18.931,51$ \\
\hline September & 5,64 & & 714,59 & $21.437,64$ \\
\hline Oktober & 5,18 & & 656,31 & $20.345,49$ \\
\hline November & 4,07 & & 515,67 & $15.470,07$ \\
\hline Desember & 3,8 & & 481,46 & $14.925,26$ \\
\hline \multicolumn{4}{|c|}{ Total (Energy Yield) } & $211.458,499$ \\
\hline
\end{tabular}

Pada skenario 2 total energi yang dapat dibangkitkan PLTS sebesar 211.458,499 kWh atau sebesar 211.46 MWh.

Tabel IX menunjukkan perhitungan energi yang menyuplai beban stadion pada skenario 2

TABEL IX

\begin{tabular}{|c|c|c|c|}
\multicolumn{4}{|c}{ Perhitungan Energi yang Disuplai PLTS Skenario 2 } \\
\hline \multirow{2}{*}{ Bulan } & Energi PLTS & Beban & \multirow{2}{*}{ Sisa Energi } \\
\cline { 2 - 3 } & Skenario 2 & Trafo 1 & \\
\cline { 2 - 3 } & \multicolumn{3}{|c}{ kWh } \\
\hline Oktober & 20.345 & 17.915 & 2.430 \\
\hline November & 15.470 & 18.724 & 0 \\
\hline Desember & 14.925 & 9.765 & 5.161 \\
\hline Januari & 16.143 & 17.857 & 0 \\
\hline Februari & 15.113 & $7.798,8$ & 7.314 \\
\hline Maret & 19.560 & 12.527 & 7.033 \\
\hline April & 19.385 & 12.160 & 7.225 \\
\hline Mei & 19.128 & 888 & 18.240 \\
\hline Juni & 13.227 & 633 & 12.594 \\
\hline Juli & 17.792 & 438 & 17.354 \\
\hline Agustus & 18.932 & 303 & 18.629 \\
\hline September & 21.438 & 1.909 & 19.528 \\
\hline Jumlah & 211.459 & 100.919 & 110.540 \\
\hline & & & \\
\hline
\end{tabular}

Pada Skenario 2, beban stadion yang dapat disuplai PLTS hanya beban pada trafo 2. Dari jumlah energi PLTS pada skenario 1 sebesar $211.459 \mathrm{kWh}$ mampu menyuplai beban trafo 1 sebanyak $100.919 \mathrm{kWh}$ dan sisa energi dapat dijual ke grid sebanyak 110.540 kWh. Pada bulan November dan Januari Energi dihasilkan PLTS tidak bisa menyuplai semua kebutuhan siang hari stadion.

Gallant Pradika: Potensi Pemanfaatan Atap Tribun ...

\section{Suplai Daya PLTS Skenario 2}

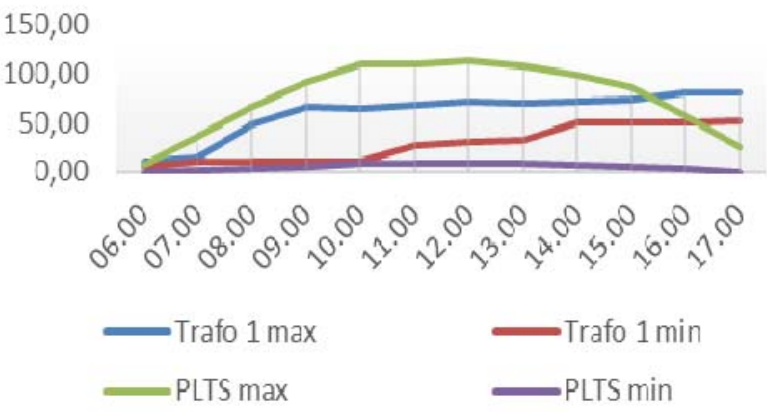

Gambar 7. Grafik Suplai PLTS Terhadap Beban Skenario 2

Pada Gambar 7 pada saat PLTS beroperasi dalam keadaan maksimum energi yang disuplai PLTS sanggup memenuhi kebutuhan beban trafo 1 kemudian energi yang tersisa akan tersalurkan ke grid. Begitu pula sebaliknya saat PLTS tidak beroperasi secara maksimum, kekurangan energi yang tidak dapat di suplai PLTS akan suplai oleh grid PLN. Hal ini dipengaruhi oleh cuaca pada saat PLTS beroperasi.

\section{F. Perancangan Single Line Diagram Stadion Kapten I Wayan Dipta Gianyar}

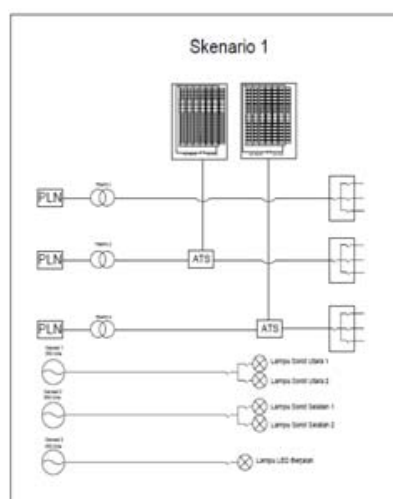

(a)

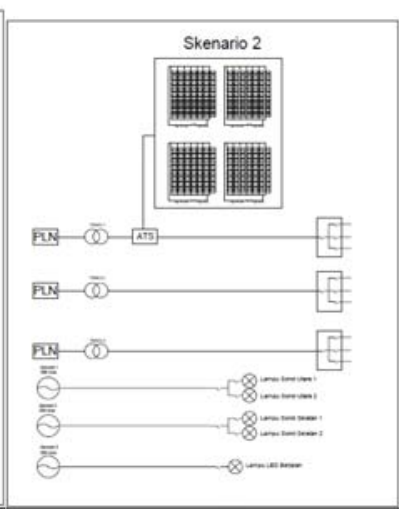

(b)
Gambar 8. (a) Single Line Diagram Skenario 1, (b) Single Line Diagram Skenario 2

Pada Gambar 8 menunjukkan single line diagram dengan skenario 1 PLTS akan menyuplai trafo 2 dan 3 sedangkan pada skenario 2 PLTS akan menyuplai beban trafo 1 .

\section{G. Perancangan Ekonomis PLTS Atap Stadion Kapten I Wayan Dipta}

Investasi PLTS atap stadion Kapten I Wayan Dipta meliputi biaya komponen PLTS dan biaya instalasi PLTS. Perhitungan biaya investasi PLTS ditunjukkan pada Tabel X

p-ISSN:1693 - 2951; e-ISSN: 2503-2372 
TABEL X

Perhitungan biaya investasi PLTS

\begin{tabular}{|c|c|c|c|c|c|c|}
\hline \multirow{2}{*}{ Komponen } & \multirow{2}{*}{ Satuan } & \multirow{2}{*}{ Harga } & \multicolumn{2}{|c|}{ Jumlah } & \multicolumn{2}{|c|}{ Total } \\
\hline & & & Sk1 & Sk2 & Sk1 & Sk2 \\
\hline \multicolumn{7}{|c|}{ Biaya Langsung } \\
\hline $\begin{array}{l}\text { Modul Surya } \\
\text { CSUN, } \\
\text { CSUN350- } \\
72 \mathrm{M}\end{array}$ & Unit & Rp3.800.000 & 238 & 448 & Rp904.400.000 & Rp1.702.400.000 \\
\hline $\begin{array}{l}\text { Inverter } \\
\text { Huawei } \\
\text { technologies } \\
\text { type } \\
\text { SUN2000 } \\
42 \mathrm{KTL}\end{array}$ & Unit & Rp74.600.000 & 2 & 4 & Rp149.200.000 & Rp298.400.000 \\
\hline $\begin{array}{c}\text { Support } \\
\text { Modul/Rak } \\
\text { Panel Surya }\end{array}$ & Unit & Rp120.000 & 238 & 448 & Rp28.560.000 & Rp53.760.000 \\
\hline \multicolumn{7}{|c|}{ Biaya Tidak Langsung } \\
\hline $\begin{array}{l}\text { Pemasangan } \\
\text { dan Instalasi }\end{array}$ & kali & & & & Rp60.000.000 & Rp114.400.000 \\
\hline $\begin{array}{c}\text { Biaya } \\
\text { Pengiriman }\end{array}$ & kali & Rp154.000 & 238 & 448 & Rp36.600.000 & Rp68.900.000 \\
\hline Total & & & & & Rp1.178.760.000 & Rp2.237.860.000 \\
\hline
\end{tabular}

. Total biaya investasi PLTS Atap tribun stadion Kapten I Wayan Dipta sebesar Rp. 1.178.760.000 untuk skenario 1 dan Rp. 2.37.860.000 untuk skenario 2. Kemudian menghitung biaya operasional dengan persamaan [13].

$$
\mathrm{AOM}=1 \% \times \mathrm{I}
$$

Skenario $1 \quad$ AOM $1=1 \% \times$ Rp 1.053 .600 .000

Skenario 2

AOM 1= Rp10.536.000 Pertahun

AOM 2=1\%× Rp2.000.800.000

AOM 2 $=$ Rp20.008.000 Pertahun

Perancangan PLTS pada atap tribun stadion tidak menggunakan sistem penyimpanan berupa baterai, maka ketika PLTS menghasilkan energi listrik, maka akan menyuplai seluruh beban pada siang hari. Namun, jika energi listrik yang dihasilkan melibihi beban yang dibutuhkan maka energi tersebut akan masuk ke grid PLN. Begitu pula sebaliknya jika energi PLTS tidak cukup untuk menyuplai beban ataupun beban saat malam hari stadion maka grid PLN akan menyalurkan energi untuk memenuhi kebutuhan beban stadion. Maka dari itu diperlukan adanya biaya penjualan dan pembelian energi listrik.

Stadion Kapten I Wayan Dipta memiliki 3 buah trafo masing-masing daya terpasangnya adalah 197kVA, $66 \mathrm{kVA}$ dan $82,5 \mathrm{kVA}$ dikategorikan pada golongan B-2/TM dengan biaya energi perkWh nya sebesar Rp.1.467. Menurut Peraturan Menteri ESDM No.49 tahun 2018 menyebutkan harga jual energi listrik dari PLTS sebesar 65\% dari harga tarif PLN. Maka dapat dihitung harga penjualan energi PLTS ke grid sebesar Rp.953. maka dapat dihitung penjualan energi tiap bulannya. Perhitungan harga jual energi dapat dilihat pada Tabel XI.

TABEL XI

Perhitungan Harga Jual Energi

\begin{tabular}{|c|c|c|c|c|}
\hline \multirow{2}{*}{ Bulan } & \multicolumn{2}{|c|}{ kWh Jual } & \multicolumn{2}{c|}{ Harga Jual } \\
\cline { 2 - 5 } & Sk1 & Sk2 & Sk1 & Sk2 \\
\hline Oktober & 3.277 & 2.430 & Rp3.123.206 & Rp2.315.934 \\
\hline November & 3.373 & 0 & Rp3.214.820 & Rp0 \\
\hline Desember & 4.268 & 5.161 & Rp4.067.837 & Rp4.918.025 \\
\hline Januari & 4.850 & 0 & Rp4.622.368 & Rp0 \\
\hline Februari & 4.361 & 7.314 & Rp4.155.688 & Rp6.970.250 \\
\hline
\end{tabular}

\begin{tabular}{|c|c|c|c|c|}
\hline Maret & 4.258 & 7.033 & $\mathrm{Rp} 4.057 .470$ & $\mathrm{Rp} 6.702 .649$ \\
\hline April & 3.664 & 7.225 & $\mathrm{Rp} 3.491 .617$ & $\mathrm{Rp} 6.885 .344$ \\
\hline Mei & 2.297 & 18.240 & $\mathrm{Rp} 2.188 .850$ & $\mathrm{Rp} 17.382 .625$ \\
\hline Juni & 1.609 & 12.594 & $\mathrm{Rp} 1.533 .282$ & $\mathrm{Rp} 12.002 .539$ \\
\hline Juli & 952 & 17.354 & $\mathrm{Rp} 906.875$ & $\mathrm{Rp} 16.538 .819$ \\
\hline Agustus & 948 & 18.629 & $\mathrm{Rp} 903.444$ & $\mathrm{Rp} 17.752 .970$ \\
\hline September & 1.613 & 19.528 & $\mathrm{Rp} 1.537 .570$ & $\mathrm{Rp} 18.610 .510$ \\
\hline Jumlah & 35.470 & 110.540 & $\mathrm{Rp} 33.803 .026$ & $\mathrm{Rp} 105.344 .518$ \\
\hline
\end{tabular}

Pada Tabel XI didapatkan hasil perhitungan harga jual energi pertahunnya yaitu sebesar Rp. 33.803.026 untuk skenario 1 dan Rp. 105.344 .518 untuk skenario 2. dapat dihitung pula penghematan pembayaran energi listrik sebelum dan sesudah dipasang PLTS dengan nilai penghematan sebesar Rp.55.596.367. untuk skenario 1 dan Rp 140.758.357 untuk skenario 2.

Analisis untuk menghitung apakah perancangan PLTS atap pada stadion Kapten I Wayan Dipta layak atau tidak menggunakan metode perhitungan Net Present Value (NPV), Profitability Index (PI) dan Discounted Payback Period (DPP). Dimana untuk menghitung NPV, PI, dan DPP dibutuhkan nilai Net Cash Flow (NCF), faktor diskonto dan Present Value Net Cash Flow atau nilai arus kas bersih sekarang.

Menentukan Net Cash Flow atau nilai arus bersih adalah dengan menghitung arus kas masuk yang dikurangi arus kas keluar. Dimana pada perancangan PLTS ini arus kas yang masuk berupa penghematan pembayaran energi pertahun ditambah biaya energi yang dijual pertahun. Sedangkan untuk arus kas keluar adalah biaya operasional dan pemeliharaan. Maka untuk kedua skenario arus kas masuk dapat dihitung sebagai berikut. [15]

$$
\mathrm{NCF}=\text { Arus kas masuk-Arus kas keluar }
$$

Untuk skenario 1 nilai NCF nya adalah

NCF $1=(\operatorname{Rp} 33.803 .026+R p .55 .596 .367)-\operatorname{Rp} 10.536 .000$

NCF 1=Rp89.399.393 - Rp10.536.000

NCF $1=78.863 .393$

Sedangkan untuk skenario 2

NCF $2=($ Rp105.344.518+Rp140.758.357) - Rp20.008.000

NCF 2=Rp246.102.875 - Rp20.008.000

NCF 2=Rp226.094.875

Untuk mencari nilai PVNCF yang dihasilkan maka dengan nilai arus kas bersih dikalikan dengan faktor diskonto. Dengan tingkat diskonto (i) yang digunakan sebesar 5,19\%, nilai ini diambil berdasarkan data uang beredar Bank Indonesia pertanggal 16 juli 2020. Maka untuk mencari faktor diskonto tahun ke $n$ adalah sebagai berikut.[15]

$$
\mathrm{DF}=\frac{1}{(1+i)^{n}}
$$

Jadi, faktor diskonto untuk tahun pertama adalah

$$
\begin{aligned}
& \mathrm{DF}=\frac{1}{(1+5,19 \%)^{1}} \\
& \mathrm{DF}=0,95
\end{aligned}
$$

Perhtungan PVNCF dapat dilihat pada Tabel XII. 
TABEL XII

Perhitungan PVNCF

\begin{tabular}{|c|c|c|c|c|c|}
\hline \multirow{3}{*}{$\mathrm{T}$} & \multicolumn{2}{|c|}{ Arus kas Bersih } & \multirow{2}{*}{$\begin{array}{c}\text { Faktor } \\
\text { Diskonto }\end{array}$} & \multicolumn{2}{|c|}{ PVNCF } \\
\hline & Sk 1 & Sk 2 & & Sk 1 & Sk 2 \\
\hline & \multicolumn{2}{|c|}{$\mathrm{Rp}$. } & & \multicolumn{2}{|c|}{ Rp. } \\
\hline 1 & 78.863 .393 & 226.094 .875 & 0,95 & 74.972 .329 & 214.939 .514 \\
\hline 2 & 78.863 .393 & 226.094 .875 & 0,90 & 71.273 .248 & 204.334 .551 \\
\hline 3 & 78.863 .393 & 226.094 .875 & 0,86 & 67.756 .676 & 194.252 .829 \\
\hline 4 & 78.863 .393 & 226.094 .875 & 0,82 & 64.413 .610 & 184.668 .532 \\
\hline 5 & 78.863 .393 & 226.094 .875 & 0,78 & 61.235 .488 & 175.557 .118 \\
\hline 6 & 78.863 .393 & 226.094 .875 & 0,74 & 58.214 .172 & 166.895 .254 \\
\hline 7 & 78.863 .393 & 226.094 .875 & 0,70 & 55.341 .926 & 158.660 .761 \\
\hline 8 & 78.863 .393 & 226.094 .875 & 0,67 & 52.611 .395 & 150.832 .551 \\
\hline 9 & 78.863 .393 & 226.094 .875 & 0,63 & 50.015 .586 & 143.390 .580 \\
\hline 10 & 78.863 .393 & 226.094 .875 & 0,60 & 47.547 .853 & 136.315 .791 \\
\hline 11 & 78.863 .393 & 226.094 .875 & 0,57 & 45.201 .875 & 129.590 .066 \\
\hline 12 & 78.863 .393 & 226.094 .875 & 0,54 & 42.971 .647 & 123.196 .184 \\
\hline 13 & 78.863 .393 & 226.094 .875 & 0,52 & 40.851 .456 & 117.117 .772 \\
\hline 14 & 78.863 .393 & 226.094 .875 & 0,49 & 38.835 .874 & 111.339 .264 \\
\hline 15 & 78.863 .393 & 226.094 .875 & 0,47 & 36.919 .740 & 105.845 .864 \\
\hline 16 & 78.863 .393 & 226.094 .875 & 0,45 & 35.098 .146 & 100.623 .504 \\
\hline 17 & 78.863 .393 & 226.094 .875 & 0,42 & 33.366 .428 & 95.658 .812 \\
\hline 18 & 78.863 .393 & 226.094 .875 & 0,40 & 31.720 .152 & 90.939 .074 \\
\hline 19 & 78.863 .393 & 226.094 .875 & 0,38 & 30.155 .103 & 86.452 .204 \\
\hline 20 & 78.863 .393 & 226.094 .875 & 0,36 & 28.667 .271 & 82.186 .714 \\
\hline 21 & 78.863 .393 & 226.094 .875 & 0,35 & 27.252 .848 & 78.131 .680 \\
\hline 22 & 78.863 .393 & 226.094 .875 & 0,33 & 25.908 .212 & 74.276 .718 \\
\hline 23 & 78.863 .393 & 226.094 .875 & 0,31 & 24.629 .919 & 70.611 .957 \\
\hline 24 & 78.863 .393 & 226.094 .875 & 0,30 & 23.414 .697 & 67.128 .014 \\
\hline 25 & 78.863 .393 & 226.094 .875 & 0,28 & 22.259 .432 & 63.815 .965 \\
\hline & & Total & & 1.090 .635 .084 & 3.126 .761 .273 \\
\hline
\end{tabular}

Pada Tabel XII dapat dilihat hasil perhitungan PVNCF pada tahun ke-25 untuk masing-masing skenario sebesar Rp.1.090.635.084 dan Rp. 3.126.761.273. kemudian menghitungan analisis ekonominya.

1. Net Present Value (NPV)

Nilai Net Present Value dapat dihitung dengan total arus kas bersih dikalikan faktor diskonto tiap tahunnya dikurangi Initial Investment. Atau dapat dirumuskan pada persamaan (1) Untuk skenario 1 nila NVP nya adalah

NPV 1=Rp1.090.635.084 -Rp 1.178.760.000

NPV 1=-Rp88.124.916

Sedangkan untuk skenario 2, nilai NPV nya sebagai berikut NPV 2=Rp3.126.761.273 -Rp 2.237.860.000

NPV 2=Rp888.901.273

PLTS dapat dikatakan layak jika nilai NPV lebih dari 0 $(0<)$. Maka pada perancangan PLTS, untuk skenario 1 nilai Gallant Pradika: Potensi Pemanfaatan Atap Tribun ...
NPV nya sebesar -Rp88.124.916 tidak layak karena nilai NPV kurang dari 0 , sedangkan untuk skenario 2 dapat dikatakan layak karena NVP lebih dari 0 yaitu Rp888.901.273.

2. Profitability Index

Perancangan PLTS dapat dikatakan layak jika nilai Profitability Index nya $(>1)$. Nilai Profitability Index dapat dihitung dengan persamaan (2).

Untuk skenario 1 nila PI nya adalah

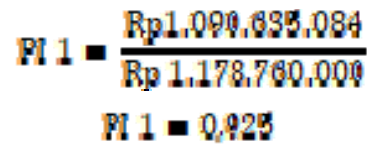

Sedangkan untuk skenario 2, nilai NPV nya sebagai berikut

\section{$M 2=\frac{R p 8,126,761,278}{R B 2,28 \%, 860,000}$ FI $2=1.89$}

Jadi pada perancangan PLTS ini, skenario 2 dapat dikatakan layak karena nilai PI nya $1,39>1$. Dan skenario 1 tidak layak, karena nila PI nya $0,925<1$.

\section{Discounted Payback Period}

Nilai Discounted Payback Period diperoleh dengan menghitung berapa tahun jumlah PVNCF akan sama atau lebih dengan nilai investasi awal.

Pada skenario 1 dihitung kembali seperti tabel 4.20 sampai tahun ke 30 dimana didapatkan hasil nilai PVNCF kumulatif tahun ke-29 mendekati nilai investasi awal. Nilai PVNCF kumulatif tahun ke-29 dengan investasi awal adalah Rp9.541.193. sedangkan pada tahun ke-30 PVNCF sebesar Rp17.283.902. maka waktu yang diperlukan untuk menutupi kekurangan investasi adalah Rp9.541.193/ Rp17.283.902 = 6 Bulan. Jadi total waktu yang dibutuhkan untuk menutupi investasi awal adalah 29 tahun 6 bulan. Sehingga dapat dikatakan investasi tidak layak karena DPP lebih lama dibandingkan umur proyek (25 tahun).

Pada skenario 2 nilai kumulatif PVNCF tahun ke-14 mendekati nilai investasi awal. Selisih nilai PVNCF kumulatif tahun ke-14 dengan investasi awal sebesar Rp26.769.231. sedangkan nilai PVNCF tahun ke-15 adalah Rp105.845.864 maka waktu yang diperlukan untuk menutupi kekurangan investasi adalah Rp26.769.231/ Rp105.845.864 = 3 bulan. Jadi total waktu yang dibutuhkan untuk menutupi investasi awal pada skenario 2 adalah 14 tahun 3 bulan. Sehingga dapat dikatakan investasi layak karena DPP lebih kecil dibandingkan umur proyek (25 tahun).

\section{KESIMPULAN}

Berdasarkan analisa dan pembahasan perancangan PLTS atap tribun stadion Kapten I Wayan Dipta Gianyar dapat disimpulkan bahwa perancangan dibagi menjadi 2 skenario, skenario 1 modul surya dipasang pada bagian sisi utara atap tribun stadion dengan jumlah 238 buah dan 2 buah inverter 42 $\mathrm{kW}$, sehingga daya yang dapat dibandingkan pada skenario 1 sebesar $83.300 \mathrm{Wp}$. Sedangkan pada skenario modul surya dipasang pada kedua sisi atap, didapat ada 448 unit modul surya dengan inverter $42 \mathrm{~kW}$ sebanyak 4 unit, maka daya yang dapat dibangkitkan pada skenario 2 sebesar $156.800 \mathrm{Wp}$.

p-ISSN:1693 - 2951; e-ISSN: 2503-2372 
Energi yang dapat dihasilkan kedua skenario tersebut dihitung secara manual dan secara simulasi menggunakan Software PVSYST. Perhitungan secara manual didapatkan energi dari PLTS sebesar 112,32 MWh/tahun untuk skenario 1 dan 211,46 MWh/tahun untuk skenario 2.

Energi yang dihasilkan PLTS berguna untuk menyuplai beban saat stadion digunakan, sistem yang digunakan pada PLTS tidak menggunakan baterai sebagai alat penyimpan energi. Sehingga beban yang dapat disuplai hanya beban siang pada saat stadion digunakan. Pada skenario 1 PLTS hanya mampu menyuplai beban pada trafo 2 dan 3. Dimana beban siang kedua trafo tersebut sebesar 35,47 MWh/pertahun yang sepenuhnya akan disuplai PLTS dan energi yang tersisa sebesar 76,85 MWh/tahun. Pada skenario 2 PLTS hanya mampu menyuplai trafo 1 saja. Dimana beban siang trafo 1 sebesar 100,91 MWh/tahun akan disuplai sepenuhnya oleh PLTS, dan memiliki sisa energi sebesar 110,54 MWh/tahun yang akan disalurkan ke jaringan PLN.

Setelah dilakukan analisis ekonomi pada perancangan PLTS, dimana untuk skenario 1 biaya investasi sebesar sebesar Rp.1.178.760.000 dan skenario 2 sebesar

Rp.2.237.860.000. Hasil perhitungan manual dengan penjualan energi sebesar Rp.953/kWh memiliki pemasukan pada tahun ke-25 sebesar Rp.1.090.635.084 untuk skenario 1 dan Rp.3.126.761.273 untuk skenario 2. Pada analisis kelayakan investasi menggunakan metode NPV, PI, dan DPP hanya skenario 2 yang dapat dikatakan layak karena pada tahun ke-25 pendapatan lebih besar dari investasi, sedangkan pada skenario 1 pendapatan akan bernilai sama dengan investasi saat tahun ke-29. Hal ini berarti sistem pada skenario 1 tidak layak karena memiliki DPP lebih lama dibandingkan umur proyek.

\section{REFERENSI}

[1] Direktorat Jenderal Ketenagalistrikan Kementerian Energi dan Sumber Daya Mineral. 2018. Statistik Ketenagalistrikan 2017.

[2] Direktoral Jenderal Ketenagalistrikan Kementerian Energi dan Sumber Daya Mineral. 2013.

[3] I. N. S. Kumara, W. G. Ariastina, I. W. Sukerayasa and I. A. D. Giriantari, "On the potential and progress of renewable electricity generation in Bali," 2014 6th International Conference on Information Technology and Electrical Engineering (ICITEE), Yogyakarta, 2014 pp. 1-6, doi: 10.1109/ICITEED.2014.7007944.Peraturan Gubernur Bali Nomor 45 Tahun 2019. Tentang Bali Energi Bersih. 2019.

[4] I.N.S Kumara, I.A.D. Giriantari, W.G. Ariastina, W. Sukerayasa, N. Setiawan, C.G.I. Partha, "Peta Jalan Pengembangan PLTS Atap : Menuju Bali Mandiri Energi, Center for Community Based Renewable Energy (CORE) Universitas Udayana, Greenpeace Indonesia, Bali, 2019.

[5] Peraturan Presiden no, 22 tahun 2017. "Rencana Umum Energi Nasional," 2017.

[6] N.S. Gunawan, I.N.S Kumara, R. Irawati, "Unjuk Kerja Pembangkit Listrik Tenaga Surya (PLTS) 26,4 kWP pada Sistem Smart Microgrid UNUD. Jurnal Spektrum, [S.I.], v. 6, n. 3, p. 1-9, sep. 2019.

[7] M.R. Wicaksana, I.N.S Kumara, I.A.D Giriantari, "Unjuk Kerja Pembangkit Listrik Tenaga Surya Rooftop $158 \mathrm{kWp}$ pada Kantor Gubernur Bali," Jurnal Spektrum, [S.I], v. 6, n. 3 p.-107-113, Sep. 2019

[8] H. Kristiawan, I.N.S Kumara, I.A.D Giriantari, "Potensi Pembangkit Listrik Tenaga Surya Atap Gedung Sekolah di Kota Denpasar," Jurnal Spektrum, [S.I], v. 6, n. 4, p. 66-70, dec. 2019.
[9] K. Sumariana, I.N.S Kumara, W.G. Ariastina, "Desain dan Analisa Ekonomi PLTS Atap untuk Villa di Bali," Majalah Ilmiah Teknologi Elektro, 18(3), 337-346. doi:10.24843/MITE.2019.v18i03.P06. 2019

[10] D. Tan, A.K. Seng, "Handbook for Solar Photovoltaic Systems," Singapore : Energy Market Authority. 2014.

[11] I.G.A.A Putra, I.A.D Giriantari, I.N.S Kumara, "Studi Sistem Pengelolaan PLTS $15 \mathrm{~kW}$ Stand Alone dengan Metode Kano di Dusun Yeh Mampeh Kabupaten Bangli” Jurnal Teknologi Elektro Unud. Vol. 14 No. 1.2015

[12] ABB, "Technical Application" Paper No. 10 Photovoltaic Plants. s.l.:s.n. 2010.

[13] S. Soulayman, W. Sabbagh, "Solar collector optimum tilt and orientation," Open Journal of Renewable and Sustainable Energy 2, 19. 2015

[14] J.W. Agung, M. Irwan, I. Muallim, S. Supartio,"Perencanaan PLTS Untuk Wilayah Kabupaten Gowa Dusun Pakkulompo Provinsi SulSel,” Makalah. Politeknik Negeri Ujung Pandang. Makassar. 2012.

[15] H.J. Patricia, "Analisis Keekonomian Kompleks Perumahan Berbasis Energi Sel Surya (Studi Kasus: Perumahan Cyber Orchid Town Houses, Depok)," FT UI. 2012.

[16] Kashmir \& Jakfar, "Studi Kelayakan Bisnis" Edisi Revisi, Penerbit PT. Desindo Putra Mandiri, Jakarta. 2017.

[17] PT. PLN (Persero) Area Bali Timur. "Data Beban Stadion Kapten I Wayan Dipta Gianyar Bali” 2020.

[18] L.E. Bien, dkk, "Perancangan system Hibrid Pembangkit Listrik Tenaga Surya Dengan Jala-Jala Listrik PLN Untuk Rumah Perkotaan," Jakarta: Teknik Elektro Universitas Trisakti. 2008

[19] P.A. Sujana, I.N.S Kumara., I.A.D Giriantari., "Pengaruh Kebersihan Modul Surya Terhadap Unjuk Kerja PLTS,” E-Journal Spektrum Vol. 2, No. 3. 2015.

[20] R. Hariyati, M.N. Qosim, A.W. Hasanah, "Konsep Fotovoltaik Terintegrasi On Grid dengan Gedung STT.PLN" Energi dan Kelistrikan : Jurnal Ilmiah Vol. 11, No. 1. 2019. 